\title{
FORMULATION OF RICE FLOUR BABY RUSK
}

\section{By}

Kottegodage Shyamaalie Lakshmi Perera

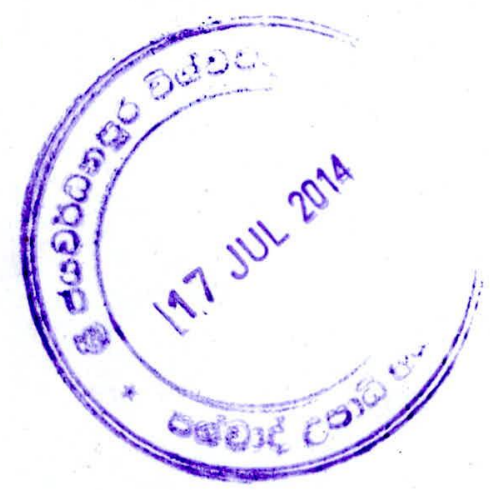

MSc 


\title{
FORMULATION OF RICE FLOUR BABY RUSK
}

\author{
By
}

Kottegodage Shyamaalie Lakshmi Perera

Thesis submitted in partial fulfillment of the requirement for the degree of Master in food science and technology, Faculty of Graduate Studies, University of Sri Jaywardenepura, Sri Lanka 


\section{Declaration}

The work described in this thesis was carried out by me at the laboratory of Food science and technology of University of Sri Jayawardenapura under the supervision of Prof. K.K.D.S. Ranaweera and Dr. Indira Wicramasinghe and a report on this thesis has not been submitted to any university for another degree and has not been presented or accepted in any previous application for a degree.

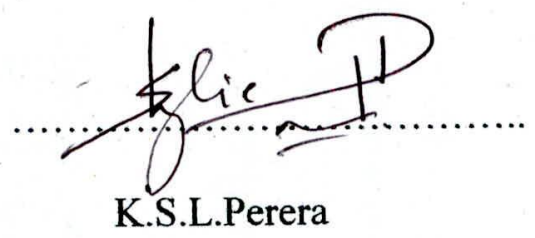


We, Prof. K.K.D.S. Ranaweera and Dr. Indira Wicramasinghe certify that the statement in preceding page made by the candidate is true and this thesis is suitable for submission to the university for the purpose of evaluation.

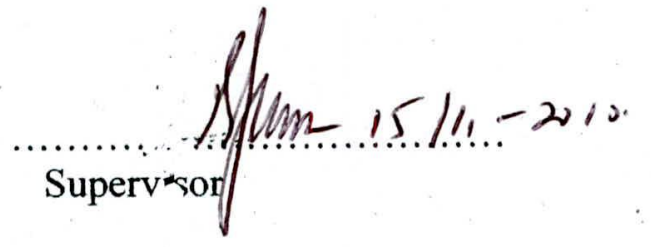

Prof. K.K.D.S. Ranaweera

Department of food science and

Technology.

University of Sri Jayawardenapura,

Gangodawila

Nugegoda

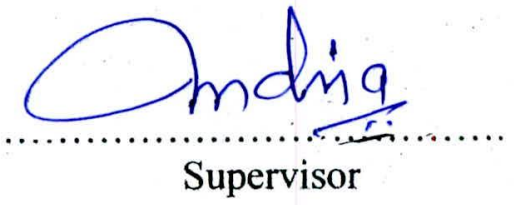

Dr. Indira Wicramasinghe

Department of food science and

Technology

University of Sri Jayawardenapura

Gangodawila

Nugegoda 
Dedicated to my loving husband and little daughter. 


\section{TABLE OF CONTENT}

Table of content

List of tables

List of figures

List of graphs

Acknowledgement

Abstract

Chapter 01

1.0 Introduction

1.2 Aim of product development

1.2.1 Overall objectives of the new product development

1.2.2 Specific objectives

Chapter 02

2.0 Literature Survey

2.1 Biscuit Technology

2.1.1 Dough mixture

2.1.2 Rotatory Moulder

2.1.3 Rotatory cutter

2.1.4 Biscuit baking Oven

2.1.5 Cooling conveyor and stacking machine

2.1.6 Biscuit Packaging machine

2.1.7 Classification of biscuits

2.2 Baking

2.3 Rice flour

2.3.1 Structure of grain

2.3.2 Rice classification

2.3.3 Gross nutrient composition

2.3.4 Starch

2.3.5 Protein

2.3.6 Lipid

2.3.7 Non- starch polysaccharide

2.3.8 Volatiles

$\begin{array}{ll}2.3 .9 \text { Rice flours and starch } & 21\end{array}$

$\begin{array}{ll}2.4 & \text { Margarine } \\ 2.4 .1 & 22\end{array}$

2..4.1 Manufacturing and properties $\quad 22$

2.4.2 Composition $\quad 23$

2.5 Banana 24

2.5.1 Toxic substances and antinutritional factors $\quad 26$

$\begin{array}{lll}2.6 & \text { Sucrose } & 27\end{array}$

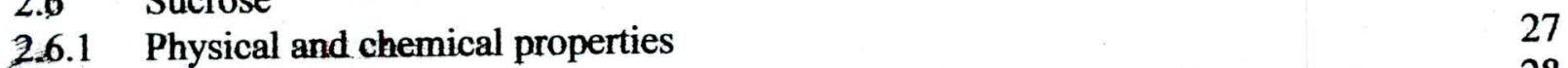

2.7 Vanilla 28

$\begin{array}{lll}2.7 .1 & \text { Chemistry } & 29\end{array}$

$\begin{array}{lll}2.7 .2 & \text { Production } & 30\end{array}$ 
$\begin{array}{ll}\text { 2.7.2.1 Natural Production } & 30\end{array}$

2.7.2.2 Chemical synthesis 31

$\begin{array}{lll}2.7 & \text { Baking powder } & 32\end{array}$

$2.8 \quad$ Functions of food packagine 33

2.8.1 Packaging has several objectives 33

2.8.2 Flexible films $\quad 34$

2.8.3 single films 35

$\begin{array}{lll}2.8 .4 & \text { Coated films } & 38\end{array}$

$\begin{array}{ll}2.8 .5 & \text { Laminated films } \\ \end{array}$

Chapter 03

$\begin{array}{lll}3.0 & \text { Methodology } & 40\end{array}$

3.1 Formulation of rice flour baby rusk 41

3.2 Proximate Analysis 42

3.2.1 Determination of moisture content 42

3.2.2 Determination of total fat 43

3.2.3 Determination of crude protein. 44

3.2.4 Determination of crude fiber 45

3.2.5 Determination of acid detergent fiber 46

3.2.6 Determination of total Ash 47

$\begin{array}{ll}\text { 3.2.8 Determination of peroxide value } & 48\end{array}$

3.2.9 Determination of acid value 49

3.2.10 Determination of total sugar and reducing sugar 50

3.3 Microbiology 52

3.3.1 Determination of Aerobic plate count 52

$\begin{array}{ll}\text { 3.3.2 Determination of salmonella } & 53\end{array}$

3.3.3 Determination of Yeast and mold count 65

3.3.4 Determination of coliform count 68

3.3.5 Determination of staphylococcus aureus 71

3.4 Sensory Evaluation 72

3.5 Selection of suitable packaging 73

Chapter 04

4.0 Results, calculations and Discussion $\quad 74$

4.1 Baby rusk result $\quad 74$

4.2.1 Determination of Moisture $\quad 74$

4.1.2 Determination of ash $\quad 76$

4.1.3 Determination of crude fiber 78

4.1.4 Determination of acid detergent fiber $\quad 80$

4.1.5 Determination of total Fat $\quad 82$

4.1.6 Determination of Crude proteins 84

4.1.7 Determination of peroxide value $\quad 86$

4.1.8 Determination of free fatty acid 88

4.1.8 Determination of total sugar and reducing sugar 91

4.1.10 Calculation of carbohydrate Percentage 93

4.2 Microbiological calculations 94 
4.2.1 Aerobic Plate count $\quad 94$

4.2.2 Yeast and mold count $\quad 95$

4.2.3 MPN/E- Coli count $\quad 95$

$\begin{array}{ll}\text { 4.2.4 Staphylococcus aureus count } & 95\end{array}$

iii

4.2.5 Salmonella count $\quad 95$

4.3 Results of minitab evaluation $\quad 97$

4.3.1 Result of Kruskas-wallis test $\quad 102$

$\begin{array}{ll}\text { 4.3.2 Result of Friedman test } & 102\end{array}$

4.4 Result for selection of suitable packaging $\quad 104$

$\begin{array}{lll}\text { 4.4.1 Moisture variation with packaging } & 104\end{array}$

$\begin{array}{ll}\text { 4.4.2 Peroxide variation with packaging } & 105\end{array}$

4.4.3 Aerobic Plate count variation with packaging $\quad 106$

$\begin{array}{ll}\text { 4.4.4 Free fatty acid variation with packaging } & 107\end{array}$

Chapter 05

$\begin{array}{lll}5.0 & \text { Conclusions } & 109\end{array}$

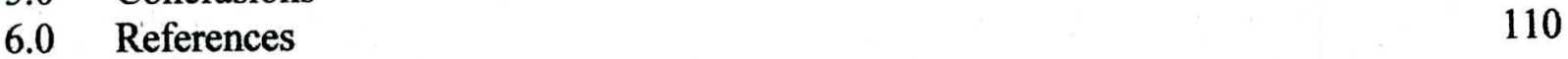

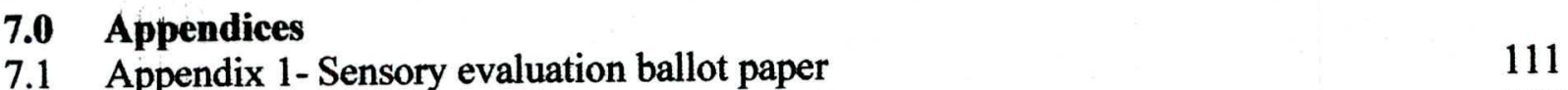

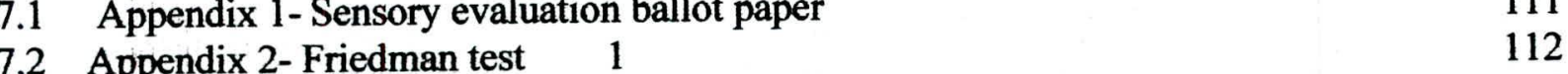

7.2 Appendix 2-Kruskal-Wallis Test 114

7.4 Appendix 4- Technological Evaluation of Shelf Life of Foods 117

7.5 Appendix 5 - coliform count plate (3M interpretation guide) 133

7.6 Appendix 6 - Yeast and mold count plate (3M interpretation guide) 138

\section{List of tables}

Table 2.3.1 proximate Value rice grain

Table 2.3.2 Vitamins and Minerals content of rice 14

Table 2.3.3 Amino acid content of rice 15

Table 2.3.4 Aminogram of the acetic and basic sub units of rice glutelin and $\quad 18$

major and minor subunits of prolamin

Table 2.3.5. Yield and composition of defatted and protease-amylase treated

cell wall preparations obtained from different histological fractions of

milling of brown rice

Table 2.4.1 Varieties of Margarine $\quad 24$

Table 3.1.1 percentage of ingredients $\quad{ }^{4}$

$\begin{array}{ll}\text { Table 3.3.1 Biochemical and serological reactions of Salmonella. } & 63 \\ & 64\end{array}$

\begin{tabular}{ll} 
Table3.3.2. Criteria for discarding non-Salmonella cultures. & 64 \\
\hline
\end{tabular}

\begin{tabular}{lr} 
Table 4.1 Variation of moisture with time & 75 \\
\hline
\end{tabular}

Table 4.2 consumed $\mathrm{HCl}$ amount $\quad 87$

$\begin{array}{ll}\text { Table } 4.3 \text { variation of peroxide value with time } & 87\end{array}$

Table 4.4 Free fatty acid variation with time modification 
Table 4.6 Titration results

Table 4.7 Reducing sugar content and total sugar content $\quad 92$

Table 4.8 calculation of carbohydrate percentage $\quad 93$

Table 4.9Aerobic plate count variation with time $\quad 94$

Table 4.3.1Result for colour obtained via sensory ballot paper. $\quad 97$

Table 4.3.2Result for crispiness obtained via sensory ballot paper. $\quad 98$

Table 4.3.3Result for mouth feel obtained via sensory ballot paper. 99

Table 4.3.4 Result for taste obtained via sensory ballot paper. $\quad 100$

Table 4.3.5 Result for overall acceptability obtained via sensory ballot paper. $\quad 101$

Table 4.3.6 Result of Kruskal-Wallis Test in Mini Tab statistical software 102

package

$\begin{array}{ll}\text { Table 4.3.7 Result of Friedman test } & 102\end{array}$

$\begin{array}{ll}\text { Table 4.4.1Moisture variation with packaging } & 104\end{array}$

Table 4.4.2 Peroxide value variation with packaging $\quad 105$

Table 4.4.3 Aerobic plate count with packaging $\quad 106$

$\begin{array}{ll}\text { Table 4.4.4 Free fatty acid content with packaging } & 107\end{array}$

\section{List of figures}

Fig. 2.1.1 dough mixture $\quad 3$

Fig.2.1.2 Rotator moulder $\quad 4$

\begin{tabular}{ll} 
Fig. 2.1.3.Rotatory cutter & 4 \\
\hline
\end{tabular}

Fig. 2.1.4 Biscuit baking Oven $\quad 5$

Fig 2.1.5 Cooling conveyor and stacking Machine $\quad 6$

Fig. 2.1.6.Biscuit packing machine $\quad 6$

$\begin{array}{ll}\text { Fig. 2.3.1 structure of the grain } & 10\end{array}$

Fig 2.7.1 $\beta$-D-glycoside of vanillin

Fig. 2.7.2 production of vanillin from guaiacol

Fig 3.1 Flow chart for production of rice flour baby rusk $\quad 40$

$\begin{array}{ll}\text { Fig 3.3.3.1 lifting of petrifilm } & 65\end{array}$

Fig 3.3.3.2 placing of $1 \mathrm{ml}$ dilution of sample $\quad 66$

Fig 3.3.3.3 placing the lifted film back $\quad 66$

Fig 3.3.3.4 spreading of dilution $\quad 66$

Fig 3.3.3.5 spreading of dilution $\quad 67$

$\begin{array}{ll}\text { Fig 3.3.3.6 spreading of dilution } & 67\end{array}$

Fig 3.3.3.7 incubating of petrifilm 67

$\begin{array}{ll}\text { Fig 3.3.3.7 counting of colonies } & 68\end{array}$

$\begin{array}{ll}\text { Fig 3.3.4.1 lifting of petrifilm } & 69\end{array}$

Fig 3.3.4.2 placing of $1 \mathrm{ml}$ dilution of sample $\quad 69$

Fig 3.3.4.4 placing the lifted film back

$\begin{array}{ll}\text { Fig 3.3.4.5 spreading of dilution } & 70\end{array}$

Fig 3.3.4.6 spreading of dilution $\quad 70$

$\begin{array}{ll}\text { Fig 3.3.4.7 spreading of dilution } & 70\end{array}$

Fig 3.3.4.8 Incubating of petri films $\quad 71$

$\begin{array}{ll}\text { Fig 3.3.4.9 counting of colonies } & 71\end{array}$ 
Fig 4.4.1 biscuits in cellophane packaging

Fig 4.4.2 biscuit in BOPP Packaging

\section{List of graph}

Graph 01 Moisture Percentage Vs Time

Graph 02 peroxide value Vs time

88

Giaph 03 free fatty acid content Vs time 90

Graph $04 \mathrm{CFU} / \mathrm{g}$ Vs Time 95

Graph 05 moisture percentage vs time with packdging 105

Graph 06 Peroxide value variations with packaging 106

$\begin{array}{ll}\text { Graph } 07 \text { Aerobic plate count with packaging } & 107\end{array}$

Graph 08 Free fatty acid content Vs time with packaging 108 


\section{ACKNOWLEDGEMENT}

I wish to express my sincere thanks for the valuable guidance and encouragement given to me throughout this project by my supervisor Dr. Indira Wicramasinghe and Prof. K.K.D.S .Ranaweera of Department of food science, University of SriJayawardenapura.

I am greatly indebted to my husband for the immense support given to me throughout this study.

I also wish to extend my special thanks to the lab staff department of food science and technology University of Sri Jayawardenapura for the support given to me in making this effort a success. 


\title{
Formulation of Rice flour BaBy rusk
}

By

\section{Kottegodage Shyamaalie Lakshmi Perera}

\begin{abstract}
The aim of this study was to produce a baby rusk by completely replacing wheat flour by rice flour in order to eliminate the health hazards brought by the consumption of wheat flour as well as to add more value to our locally produced rice. Natural banana was used in place of water and flavour substance in this product.

Rice flour, banana, margarine, eggs, sugar, full cream milk powder, vanilla flavour and baking powder were used as the ingredients in the production of the baby rusk.

The product was evaluated for Chemical composition, keeping quality, microbial quality as well as for sensory properties such as colour, mouth feel, taste and overall acceptability. Sensory evaluation was done by using un trained panelists. All chemical and microbiological parameters were found to be in acceptable levels.
\end{abstract}

Development of flavour variations, addition of vitamin formulas could be done as further research. 


\section{Chapter 01}

\subsection{Introduction}

Wheat flour is the most commonly used type of flour in the bakery industry. This is mainly due to its high molding ability which is given by the high content of gluten. Although it contains these acceptable qualities, it also contains certain health hazards. Certain components in wheat flour tend to destroy 'Beta cells' that are responsible for the secretion of Insulin hormone which controls the sugar level of blood. This condition could eventually lead to diabetes which is now becoming common among children as well among infants. Also due to Gluten intolerance disease some people have to depend on gluten free diets. A gluten free diet means avoiding all products that contain wheat, rye and barley, or any of their derivatives. Since rice flour is free of components that destroy 'Beta cells' as well as gluten it becomes a healthy solution for both these conditions.

Rice is rich in lysine which is the first limiting amino acid. It also contains a much higher content of protein compared to wheat flour. It is also richer in B vitamins and mineral content compared to wheat flour.

Banana is a comparatively cheap and abundant fruit in Sri Lanka. Banana starch is easily digestible. This property makes it highly suitable as an ingredient in an infant food. Banana also adds pleasant flavour while providing the food product with useful minerals.

Since this product is prepared by mainly using locally available cheap ingredients, it becomes a nutritious as well as a cost effective product. 


\subsection{Aim of the product Development}

The intended purpose of the development of this product was to provide our people a healthy and cost effective infant food which is rich in nutrients gained by our own local material.

\subsubsection{Overall objectives of the new product development}

- Development of an infant food which is free of health hazards produced by wheat flour.

- Development of an infant food which is richer in proteins.

- Value addition to locally available ingredients

- Development of a product which is affordable to a wide range of consumer classes.

\subsubsection{Specific objectives}

- Determination of chemical composition of the product

- Determination of microbiological aspects regarding the shelf life of the product

- Determination of the shelf life of the product. 


\section{Chapter 02}

\section{$\underline{\text { 2.0 Literature survey }}$}

\subsection{Biscuit Technology}

The word biscuit derived from Latin words panis biscoctus, for twice-baked. Biscuit industry was started in Briton and first biscuits were dried out rusks which were used for sea journeys.

The biscuit industry today is a well-developed industry which automated machinery from dough mixtures to packaging.

\subsubsection{Dough Mixer}

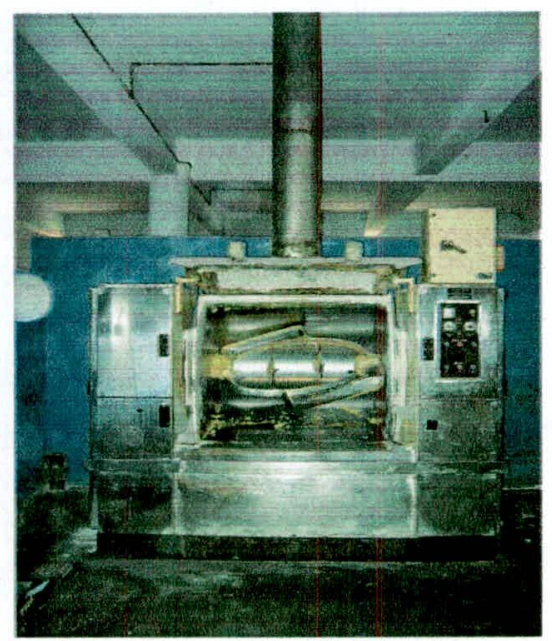

Fig 2.1.1 Dough Mixer

The machine is used for mixing various ingredients such as flour, sugar, fat, water, and other chemicals for making hard, soft or fermented dough for making biscuits.

A base plate over which two side frames are fitted for taking the load of mixing chamber which is fitted on side frames. In the mixing chamber two Z/sigma type-mixing blades are fitted which rotate at different speeds in opposite direction to mix various types of soft/hard dough for achieving required glutton of dough. 